African Crop Science Journal by African Crop Science Society is licensed under a Creative Commons Attribution 3.0 Uganda License. Based on a work at www.ajol.info/ and www.bioline.org.br/cs DOI: https://dx.doi.org/10.4314/acsj.v28i2.10

\title{
INCIDENCE OF LEAF BLIGHT DISEASE OF EGUSI MELON IN SOUTH-WEST NIGERIA
}

\author{
J.F. OGUNSOLA, B. IKOTUN and K.E. OGUNSOLA ${ }^{1}$
}

Department of Crop Protection and Environmental Biology, University of Ibadan, Nigeria

${ }^{1}$ Department of Biological Sciences, Bells University of Technology Ota, Ogun State, Nigeria

Corresponding author: ogunsolajustinah@gmail.com

(Received 30 May 2019; accepted 29 June 2020)

\begin{abstract}
Egusi melon (Citrullus lanatus (Thumb) Mansf.) is an important vegetable crop grown for edible seeds and oil in West Africa. Leaf Blight Disease (LBD) is one of the major constraints to its production, with potential to cause economic damage. The objective of this study was to investigate the incidence and distribution of leaf blight on Egusi melon in Southwestern Nigeria. A survey of LBD of Egusi melon was conducted in 2015 and 2016, in five southwestern States of Nigeria (Ogun, Oyo, Osun, Ekiti and Ondo States). Twenty plants each, were randomly sampled from 150 farms comprising 30 farms each, from each State. The distribution of different Egusi melon varieties planted was recorded. "Bara" cv. was the most cultivated variety (51.6\%); followed by "Bojuri" (30.4\%) and "Serewe" (18\%). Leaf blight was observed in most farms in the five States, from $73 \%$ in Osun and Oyo states to $83 \%$ in Ondo State. Disease incidence and severity varied with locations and cultivars, and ranged from $0.0-87.5 \pm 18 \%$ and 1.0 $\pm 0-4.5 \pm 0.8$ in Osun State to $20.0 \pm 19-95.0 \pm 4.5 \%$ and $2.3 \pm 1.5-5.0 \pm 0$ in Ondo State. Out of the twelve fungal pathogens from ten genera isolated from infected plants, only Colletotrichum truncatum, C. gloeosporioides and Lasiodiplodia theobromae caused Leaf blight on Egusi melon.
\end{abstract}

Key Words: Colletotrichum gloeosporioides, Colletotrichum truncatum, Lasiodiplodia theobromae

\section{RÉSUMÉ}

Le melon Egusi (Citrullus lanatus (Thumb) Mansf.) Est une importante culture légumière cultivée pour les graines et l'huile comestibles en Afrique de l'Ouest. La maladie de brûlure foliaire (LBD) est l'une des principales contraintes à sa production, avec le potentiel de causer des dommages économiques. L'objectif de cette étude était d'étudier l'incidence et la distribution de la brûlure foliaire du melon Egusi dans le Sud-ouest du Nigéria. Une enquête sur la LBD du melon Egusi a été faite en 2015 et 2016, dans cinq États du sud-ouest du Nigéria (États d'Ogun, Oyo, Osun, Ekiti et Ondo). Vingt plantes dans chaque État ont été échantillonnées au hasard dans 150 fermes comprenant 30 fermes chacune, de chaque État. La distribution des différentes variétés de melons Egusi plantées a été enregistrée. «Bara» cv. était la variété la plus cultivée (51,6\%); suivi de «Bojuri» $(30,4 \%)$ et «Serewe» (18\%). La brûlure foliaire a été observée dans la plupart des exploitations agricoles des cinq États, 
passant de 73\% dans les États d'Osun et d'Oyo à 83\% dans l'État d'Ondo. L'incidence et la gravité de la maladie variaient selon les emplacements et les cultivars, et allaient de $0,0-87,5 \pm 18 \%$ et $1,0 \pm 0-4,5$ $\pm 0,8$ dans l'État d'Osun à 20,0 $\pm 19-95,0 \pm 4,5 \%$ et 2,3 $\pm 1,5-5,0 \pm 0$ dans l'État d'Ondo. Sur les douze agents pathogènes fongiques de dix genres isolés de plantes infectées, seuls Colletotrichum truncatum, C. gloeosporioides et Lasiodiplodia theobromae ont causé la brûlure foliaire du melon Egusi.

Mots Clés: Colletotrichum gloeosporioides, Colletotrichum truncatum, Lasiodiplodia theobromae

\section{INTRODUCTION}

Egusi melon (Citrullus lanatus (Thumb) Mansf.) is a vegetable crop commonly cultivated in West Africa for edible nutrient rich seeds, popularly called "Egusi" in Nigeria (Denton and Olufolaji, 2000; van der Vossen et al., 2004). It belongs to the family Cucurbitaceae (Schippers, 2000). Four genera of this family, namely Cucumis, Citrullus, Cucumeropsis and Lagenaria are referred to as melon. Example of the genus Cucumis is $C$. melo L. (true melon), that of Citrullus are $C$. lanatus Thunb. Matsum and Nakai (Watermelon) and Citrullus lanatus (Thumb) Mansf. (Egusi melon). The common Cucumeropsis species is C. mannii Naud (white-seeded Egusi melon); while the species of Lagenaria (gourd melons) that is Egusi melon is Lagenaria abyssinica (Ajuru and Okoli, 2013).

The scientific name for Egusi melon has been variously given as Citrullus lunatus (Thumb.), Citrullus vulgaris Shrad or Colocynthis citrullus L. (Philip, 1977; Ogunremi, 1978). However, Lowe and Soladoye (1990) indicated that Egusi melon was formerly known as Colocynthis citrullus (Linn) O. Ktzer, but is now confirmed to be Citrullus lanatus (Thumb) Mansf. The crop is native to the West African region. It is a trailing, hairy and herbaceous crop (Agba et al., 2009), usually intercropped with other crops such as yams, sorghum and cassava, in peasant farms (Adewusi et al., 2000; Agba, 2004). Nigeria is the highest producer of melon in Africa, producing about 569, 398 tonnes over an area of $1,085,998$ ha, with an average yield of $5,243 \mathrm{~kg} \mathrm{ha}^{-1}$, followed by
Democratic Republic of Congo $(62,487$ tonnes) and Cameroun (52, 940 tonnes) (FAO, 2016).

The common Egusi melon cultivars in Nigeria are "Bara", "Serewe" (Citrullus lanatus (Thumb) Mansf) and "Bojuri" (Lagenaria abyssinica). In the South-western and Northern Nigeria, "Bara" is the most common, characterised by prominent thick, black or white colour seed edges (Oyolu, 1977; Fayemi, 1999). This cultivar has the widest distribution (Denton and Adeniran, 1990; Denton and Olufolaji, 2000). Unlike "Bara", "Serewe" lack pronounced seed edge (van der Vossen et al., 2004) and the characteristic thin seed coat; and lack of seed edge has made the "Serewe" seed to have higher shelling percentage, thus providing more edible endosperm than "Bara" (Denton and Olufolaji, 2000). "Bojuri" plant, which is broad-leaf unlike others, has bigger and longer seed than the other two, and without pronounced seed edge but usually with terminal white or brown patches.

In spite of the vast nutritional and industrial significance of Egusi melon seeds, its production and yield are very low in Nigeria, owing to many factors which include excessive rainfall, low soil $\mathrm{pH}$ and increased incidence of pathogens such as, fungi, bacteria, nematodes and viruses (van der Vossen et al., 2004). Incidence and management of a variety of diseases have been reported on other members of the family Cucurbitaceae; but little information is available on Egusi melon. Most of the time, diseases affecting this crop are described with reference to other related crops such as watermelon (C. lanatus var. lanatus), which have received more research attention. 
Fungal diseases, namely powdery mildew, downy mildew, Alternaria leaf spot, Cercospora leaf spot, Anthracnose disease (Colletotrichum lagenarium), leaf blight and fruit rot (Didymella bryoaniae) and fruit and flower wet rot (Choanephora cucurbitarum) have been reported on Egusi melon in Nigeria (Kehinde, 2008). Among these, Anthracnose and leaf blight were reported to be the predominant foliar fungal diseases of the crop in Southwestern Nigeria (Kehinde, 2011). However, there are limited reports and lack of updates on the important Egusi melon diseases, especially on the distribution and current status of blight in Nigeria. This study investigated the incidence and causal organism of leaf blight disease of Egusi melon in South Western Nigeria

\section{MATERIALS AND METHODS}

Incidence and severity of leaf blight. A field survey was conducted in Ogun, Oyo, Osun, Ekiti and Ondo states of Nigeria, during Egusi melon growing season, in the South-west Nigeria (between April and July) of 2015 and 2016. Information on the Egusi melon producing areas obtained from the Agricultural Development Projects (ADPs) of the States, was used in the choice of survey locations. Twenty blight infected symptomatic plants were randomly sampled per farm (Kehinde, 2011) with two farms per location, three locations per local government areas (LGAs) and five LGAs per State; making 150 surveyed farms from the five States. Survey was conducted by randomly walking through the farm diagonally to collect leaf samples. Georeferences of each point surveyed were determined using Global Positioning System equipment (eTrex Garmin, Taiwan).

Disease incidence on the fields was assessed using the formula:

Incidence $(\%)=\mathrm{n} / \mathrm{N} \times 100$
Where:

$\mathrm{n}=$ number of plants showing symptoms on the field;

$\mathrm{N}=$ Total number of plant on the field.

Disease severity was determined as:

Disease severity $=$

Proportion of total damaged tissue $\times 100$

Total surface area of the plant parts 1

This was converted to a disease rating scale of 1- 5 (Kehinde, 2011): 1= No symptom; $2=$ $<10 \%$ damaged portion (mild symptom); $3=$ (11 - 30\% damaged portion (moderate symptom); $4=31-50 \%$ damaged (severe symptom); $5=>50 \%$ damaged portion (very severe symptom).

The frequency of occurrence of isolated fungi was calculated following Ebele (2011) as follows:

Frequency of occurrence $(\%)=$

Number of times a fungus was encountered

Total number of fungi isolated

Isolation of fungi associated with Leaf blight disease. A diagnostic test was carried out at the Pathology Laboratory of the Nigeria Agricultural Quarantine Service, Moor Plantation Ibadan, Nigeria. Leaf samples with blight symptom were washed with sterile distilled water, and $5 \mathrm{~mm}^{2}$ of the infected parts were cut with sterile scalpel blade, at the boundary of the healthy and infected tissues. The excised leaves were sterilised for two minutes, in $10 \%$ Sodium hypochlorite (Klement et al., 1990). They were then rinsed five times with sterile distilled water and blotted to dry between sterile paper towels, before plating on potato dextrose agar (PDA). These pieces were aseptically transferred with scalpel into Petri dishes containing $15 \mathrm{~mL}$ of PDA. 
The inoculated plates were incubated at 28 $\pm 2{ }^{\circ} \mathrm{C}$ for 3 to 7 days, and examined for fungal growth using compound microscope (Navite Olympus, China). Fungal isolates from each of the samples were sub-cultured on PDA to obtain pure cultures for identification. Cultural and morphological characteristics of the fungal isolates were recorded. Wet mounts of the isolates were prepared on a microscope slide and stained with lactophenol cotton blue. The mounts were observed under a compound microscope at X40 magnification. Detailed structural features of each isolate were recorded and features of the organisms were compared with those described in a Standard Manual for Fungi (Barnett and Hunter, 2003).

Pathogenicity test. Pathogenicity test was carried out in a screenhouse, using 14 dayold Egusi melon seedlings. A fungal suspension of $2.1 \times 10^{6}$ spores $\mathrm{mL}^{-1}$ was prepared from the 7 days old culture plates of the isolated fungi. All the fungi isolated from survey sampled were used. The test was conducted in a 3 by 12 factorial (3 cultivars: "Serewe", "Bara", "Bojuri" and twelve isolates) experiment in a completely randomised design, replicated three times. Two seeds were planted per pot, filled with $5 \mathrm{~kg}$ sterilised soil, to raise seedlings on which fungal isolates were inoculated to confirm causal organisms of Egusi melon diseases.

A spore suspension of $2.1 \times 10^{6}$ spores $\mathrm{mL}^{-}$ ${ }^{1}$ was sprayed on the leaf surfaces to run off using a $250 \mathrm{~mL}$ hand-operated sprayer, and covered with a transparent polythene sheet for 48 hours to maintain high humidity for disease initiation. Control plants were sprayed with only sterile water. Appearance of blight and other disease symptoms were observed for five weeks. Daily watering of plants was carried out. Re-isolation of the pathogen was done from the plant showing disease symptoms within two to five weeks post-inoculation and isolates were identified using standard procedures (Barnett and Hunter, 2003).

Data were analysed by ANOVA, using the Statistical Analysis Software (SAS, 2008).
Means with significant differences were separated by Student Newman Keuls (SNK) Test at 5\% level of significance

\section{RESULTS AND DISCUSSION}

Three Egusi melon cvs. were found in the five States, of which "Bara" was the most cultivated $(51.6 \%)$ in all the LGAs, followed by "Bojuri" (30.4\%). "Serewe" (18\%) was least cultivated in both years. Leaf blight symptoms were observed in all the LGAs in the five States. Out of 30 farms per State, blight was observed on 22 farms (73\%) in Osun and Oyo, 23 (77 \%) in Ogun and Ekiti and 25 farms $(83 \%)$ in Ondo State. This confirms the presence of leaf blight on the crop in Nigeria, as previously reported (Chiejina, 2006; Kehinde, 2008). Blight incidence and severity were generally high across the five States, although this varied with farm locations and cultivars (Table 1). In Ogun State, the highest incidence and severity (90.0\% and 5.0) were observed on "Bojuri" cv. in Odeda LGA, with lowest $(25.0 \pm 7 \%$ and 4.0$)$ on "Bara" from Ado-odo Ota.

Ise-orun LGA had the highest leaf blight incidence and severity $(70.0 \%$ and $3.8 \pm 0.4)$ on "Bara" in Ekiti State; while "Serewe" at Ekiti West had the least $(6.7 \pm 0.5 \%$ and 2.0$)$. Ondo State had the highest incidence of leaf blight among the five States, with $95.0 \pm 4.5 \%$ incidence and $4.7 \pm 0.5$ severity on "Bojuri" at Akure North and least (20.0\% and 2.3 \pm 1.5 ) on "Bara" in Akoko North-east. Also, "Bara" cv. had the highest $(87.5 \pm 18 \%$ and $4.5 \pm 0.8)$ in Ayedire LGA of Osun State; while blight was not observed (0.0 and $1.0 \%)$ on "Bara" and "Serewe" at Ife South. The highest incidence and severity observed in Oyo State (77.0 \pm 14 and $3.8 \pm 1.3 \%)$ was on "Bara" at Ibarapa East; whereas Atisbo had the least $(35.0 \pm 20$ and $2.8 \pm 0.5 \%)$ on the same cultivar.

The observed blight incidences were generally not too distant from the range of 82 - 100\% earlier reported by Kehinde (2008). Higher leaf blight incidence and severity observed on "Bara" in three (Ekiti, Osun and 
TABLE 1. Incidence (\%) and severity of leaf blight on Egusi melon cultivars in five South Western States in Nigeria

\begin{tabular}{|c|c|c|c|c|c|c|c|}
\hline \multirow[t]{2}{*}{ State } & \multirow[t]{2}{*}{ LGA } & \multicolumn{3}{|c|}{ Incidence } & \multicolumn{3}{|c|}{ Severity } \\
\hline & & Bara cv. & Serewe cv. & Bojuri cv. & Bara cv. & Serewe cv. & Bojuri cv. \\
\hline \multirow[t]{5}{*}{ Ogun } & Odeda & $60.0 \pm 24 a$ & $40 \pm 0 \mathrm{c}$ & $90.0 \pm 0 \mathrm{a}$ & $3.8 \pm 1.5 \mathrm{a}$ & $1.5 \pm 0 b$ & $5.0 \pm 0 \mathrm{a}$ \\
\hline & Odogbolu & $56.0 \pm 11 \mathrm{a}$ & $50 \pm 11 b$ & - & $4.0 \pm 0.7 \mathrm{a}$ & $3.5 \pm 0 \mathrm{a}$ & - \\
\hline & Ijebu N.E. & $55.0 \pm 6 a$ & $70 \pm 0 \mathrm{a}$ & $40.0 \pm 0 \mathrm{~b}$ & $3.3 \pm 0.5 \mathrm{a}$ & $5.0 \pm 0 \mathrm{a}$ & $2.0 \pm 0 \mathrm{c}$ \\
\hline & Ado-odo ota & $25.0 \pm 7 b$ & $30.0 \pm 0 \mathrm{c}$ & $32.5 \pm 25 b$ & $4.0 \pm 0 \mathrm{a}$ & $4.0 \pm 0 \mathrm{a}$ & $2.5 \pm 1.0 \mathrm{c}$ \\
\hline & Yewa N. & $30.0 \pm 8 \mathrm{ab}$ & $30.0 \pm 0 \mathrm{c}$ & $32.5 \pm 5 b$ & $3.3 \pm 1.0 \mathrm{a}$ & $3.0 \pm 0 \mathrm{a}$ & $3.8 \pm 0.5 b$ \\
\hline \multirow[t]{5}{*}{ Ekiti } & Emure & $40.0 \pm 0 \mathrm{ab}$ & $40.0 \pm 0 \mathrm{a}$ & $63.3 \pm 6 a$ & $2.6 \pm 0.9 b$ & $2.0 \pm 0 \mathrm{~b}$ & $3.3 \pm 0.6 \mathrm{a}$ \\
\hline & Ise-oru & $70.0 \pm 0 \mathrm{a}$ & - & $62.0 \pm 11 \mathrm{a}$ & $3.8 \pm 0.4 \mathrm{a}$ & - & $3.2 \pm 0.5 \mathrm{a}$ \\
\hline & Ekiti S.W. & $40.0 \pm 0 \mathrm{ab}$ & - & $71.6 \pm 25 a$ & $2.0 \pm 0 \mathrm{~b}$ & - & $4.0 \pm 1.3 \mathrm{a}$ \\
\hline & Ekiti W. & $23.8 \pm 20 c$ & $6.7 \pm 0.5 b$ & $32.0 \pm 18 b$ & $2.3 \pm 1.0 \mathrm{~b}$ & $2.0 \pm 0 \mathrm{~b}$ & $2.8 \pm 0.8 \mathrm{a}$ \\
\hline & Ijero & $47.5 \pm 17 \mathrm{ab}$ & $40.0 \pm 0 \mathrm{a}$ & $57.5 \pm 27 a$ & $3.8 \pm 0.5 \mathrm{a}$ & $3.5 \pm 0 \mathrm{a}$ & $4.0 \pm 0.8 \mathrm{a}$ \\
\hline \multirow[t]{5}{*}{ Ondo } & Owo & $92.0 \pm 7 \mathrm{a}$ & $70.0 \pm 0 \mathrm{a}$ & $86.7 \pm 5.8 \mathrm{a}$ & $5.0 \pm 0.5 \mathrm{a}$ & $3.0 \pm 0 \mathrm{~b}$ & $4.3 \pm 0.6 \mathrm{ab}$ \\
\hline & Odigbo & $90.0 \pm 0 \mathrm{a}$ & $80.0 \pm 0 \mathrm{a}$ & $83.3 \pm 15.3 \mathrm{a}$ & $4.0 \pm 0 \mathrm{ab}$ & $4.0 \pm 0 \mathrm{a}$ & $4.3 \pm 0.6 \mathrm{ab}$ \\
\hline & Akure N. & - & - & $95.0 \pm 4.5 \mathrm{a}$ & - & - & $4.7 \pm 0.5 \mathrm{a}$ \\
\hline & Akoko N.E. & $20.0 \pm 19 b$ & $20.0 \pm 0 b$ & $32.5 \pm 22 b$ & $2.3 \pm 1.5 b$ & $3.0 \pm 0 \mathrm{~b}$ & $2.3 \pm 1.5 \mathrm{c}$ \\
\hline & Akoko N.W. & $27.5 \pm 17 b$ & $30.0 \pm 0 \mathrm{~b}$ & $25.0 \pm 18 b$ & $3.0 \pm 1.2 \mathrm{ab}$ & $3.0 \pm 0.4 b$ & $2.7 \pm 1.2 \mathrm{bc}$ \\
\hline \multirow[t]{5}{*}{ Osun } & Ayedire & $87.5 \pm 18 \mathrm{a}$ & $70.0 \pm 4 b$ & - & $4.5 \pm 0.8 \mathrm{a}$ & $4.0 \pm 0 \mathrm{a}$ & - \\
\hline & Iwo & $75.0 \pm 17 \mathrm{a}$ & $80.0 \pm 0 \mathrm{a}$ & - & $4.2 \pm 0.8 \mathrm{a}$ & $4.0 \pm 0 \mathrm{a}$ & - \\
\hline & Ola Oluwa & $75.0 \pm 10 \mathrm{a}$ & - & - & $4.1 \pm 0.7 \mathrm{a}$ & - & - \\
\hline & Ife S. & $0.0 \pm 0 \mathrm{c}$ & $0.0 \pm 0 \mathrm{~cd}$ & $34.0 \pm 20 \mathrm{a}$ & $1.0 \pm 0 \mathrm{~b}$ & $1.0 \pm 0 \mathrm{~b}$ & $3.2 \pm 0.8 \mathrm{a}$ \\
\hline & Ori-ade & $24.0 \pm 11 \mathrm{~b}$ & $35.0 \pm 0 \mathrm{c}$ & $26.0 \pm 9 \mathrm{a}$ & $3.4 \pm 0.6 \mathrm{a}$ & $3.5 \pm 0$ & $3.6 \pm 0.5 \mathrm{a}$ \\
\hline \multirow[t]{5}{*}{ Oyо } & Ibarapa E. & $77.0 \pm 14 \mathrm{a}$ & $58.3 \pm 4 b$ & $60.0 \pm 0 \mathrm{ab}$ & $3.8 \pm 1.3 \mathrm{a}$ & $2.0 \pm 0.6 b$ & $2.0 \pm 0 \mathrm{~b}$ \\
\hline & Ibadan S.W. & $50.0 \pm 19 b$ & $56.7 \pm 12 b$ & $70.0 \pm 0 \mathrm{a}$ & $3.6 \pm 0.6 \mathrm{a}$ & $4.0 \pm 0 \mathrm{a}$ & $4.0 \pm 0 \mathrm{a}$ \\
\hline & Ido & $35.0 \pm 16 b$ & $70.0 \pm 0 \mathrm{a}$ & - & $2.8 \pm 1.0 \mathrm{a}$ & $4.0 \pm 0 \mathrm{a}$ & - \\
\hline & Atisbo & $35.0 \pm 20 \mathrm{~b}$ & $40.0 \pm 0 \mathrm{c}$ & $35.0 \pm 16 c$ & $2.8 \pm 0.5 \mathrm{a}$ & $3.0 \pm 0.7 \mathrm{a}$ & $2.8 \pm 0 \mathrm{~b}$ \\
\hline & Iseyin & $60.0 \pm 0 \mathrm{ab}$ & $60.0 \pm 0 \mathrm{~b}$ & $50.0 \pm 12 b$ & $3.7 \pm 0.5 \mathrm{a}$ & $4.0 \pm 0 \mathrm{a}$ & $3.8 \pm 0.4 \mathrm{a}$ \\
\hline
\end{tabular}

- = variety not found, LGA = Local government area. Values are mean data of 2015 and 2016 surveys. Value with similar letter along the column for each State are not significantly different by Student Newman Keuls Test $(\mathrm{P}=0.05)$ 
Oyo) of the five States is conceivable due to wider distribution of the cultivar in Southwestern Nigeria, arising from the cultivar's better preference by the people as well as its high susceptibility to the disease. Leaf blight has been reported to have produced the highest incidence and severity compared to other folia diseases of Bara and Serewe cvs. in South-west Nigeria (Kehinde, 2011). High rainfall and humidity of South-west Nigeria, during the Egusi melon cropping season might have also contributed to the high incidence and distribution of the disease.

Fungal isolates from the samples produced some disease symptoms on Egusi melon plants (Plate 1) from the pathogenicity test. Twelve fungal pathogens from ten genera isolated and identified from the infected samples (Fig. 1)
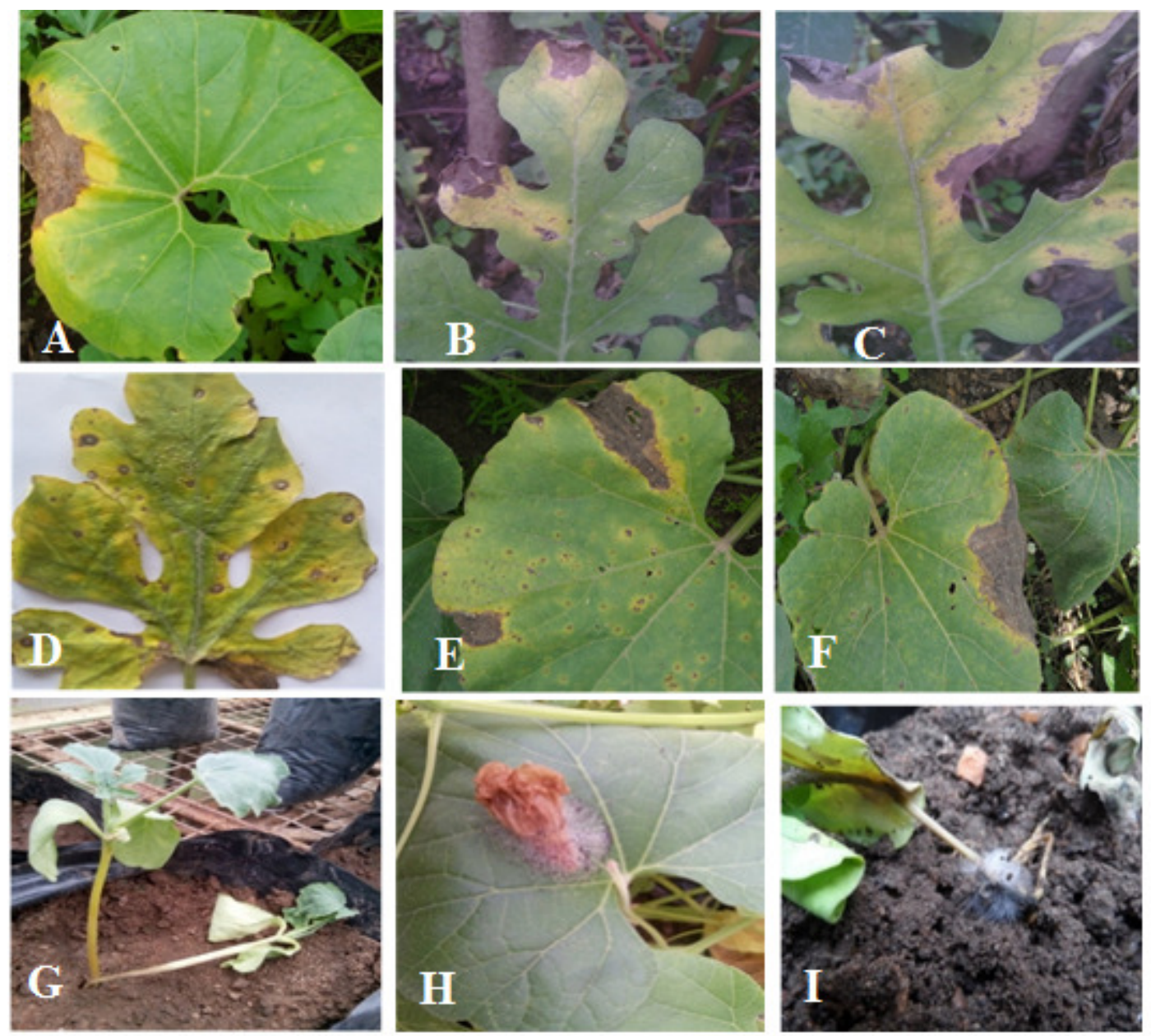

Plate 1 (A - I). Disease symptoms incited by fungi on Egusi melon cultivars: (A) Blight caused by field infection of Colletotrichum gloeosporioides on "Bojuri", (B) Blight incited naturally by C. truncatum on "Bara", (C) Blight from field infection of "Serewe" with Lasiodiplodia theobromae, (D) Leaf spot caused by Corynespora cassiicola inoculated on "Bara", (E) Blight and leaf spot on "Bojuri" by $C$. truncatum, C. gloeosporioides and Corynespora cassiicola, (F) blight on "Bojuri" by L. theobromae, (G) Damping-off caused by Fusarium solani on inoculated "Serewe" seedlings, (H) Wet rot of flowers by inoculation of Choanephora cucurbitarum on "Bojuri" and (I) Vine wilt by F. verticillioides inoculated "Serewe" seedlings. 


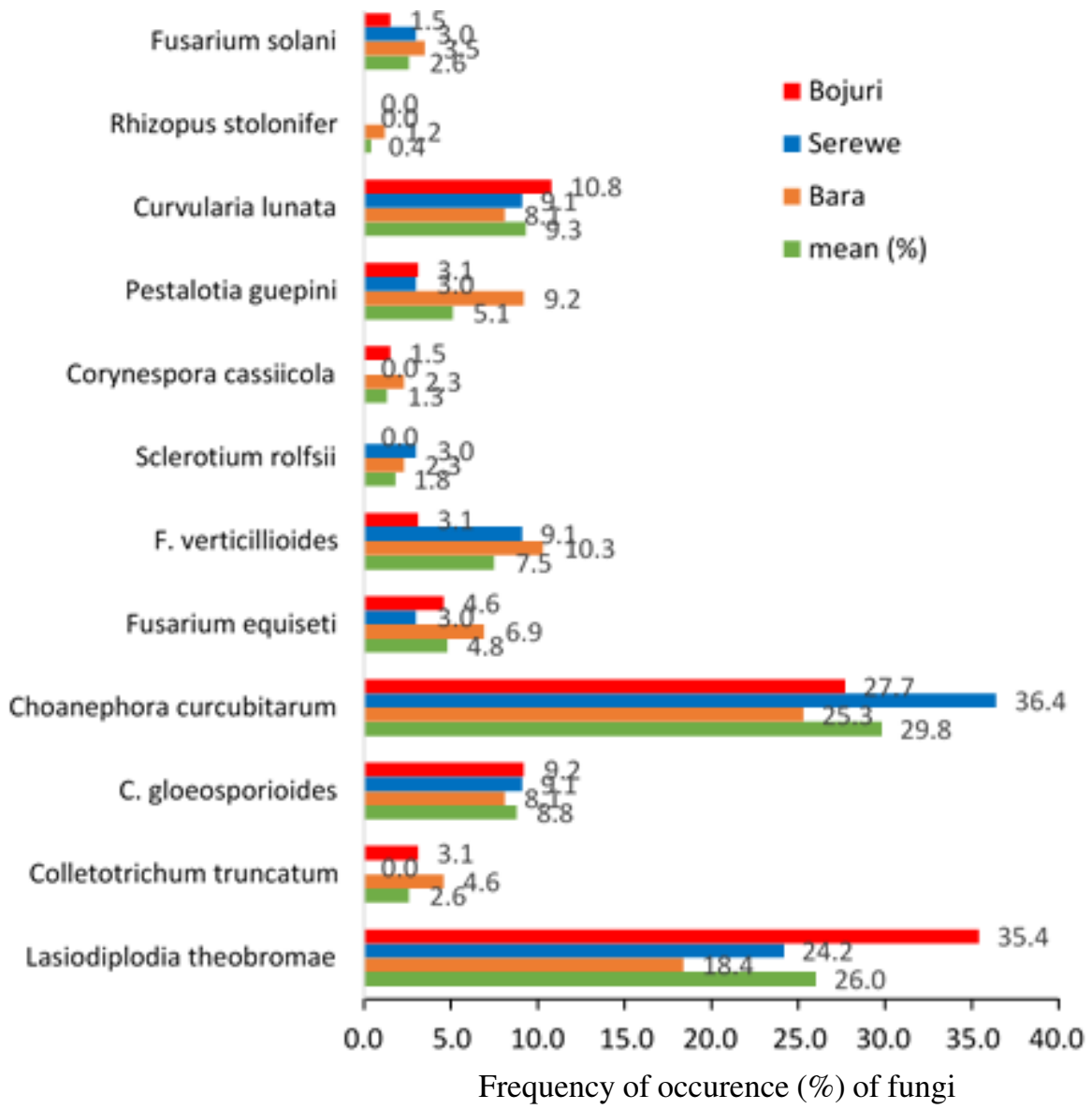

Figure 1. Frequency of occurrence of isolated fungi from blight infected Egusi melon plants in Nigeria.

had some similarity with previous reports (Bankole and Joda, 2004; Kehinde, 2011). Though there is limited information on the economically important pathogenic fungi of Egusi melon, some of these isolated fungi have been reported earlier from the crop in Southeastern Nigeria (Chiejina, 2006). Meanwhile, the available reports focussed more on stored Egusi melon seeds than field plants. For instance, a study on stored seeds of "Serewe" variety in Nigeria showed incidence of Aspergillus. niger, A. flavus, A. fumigatus, A. granulosis, F. solani, Botrydiplodia theobromae and Penicillum citrinum (Bankole and Joda, 2004).

Kehinde (2013) reported isolation of Erysiphe cucurbitarum (Powdery mildew),
Peronospora cucurbitarum, (Downy mildew) Alternaria cucumerina, (Alternaria leaf spot) Cercospora citrullina (Cercospora leaf spot), Colletotrichum lagenarium (Anthracnose), Didymella bryoaniae (leaf and vine blight and fruit rot) and C. cucurbittarum (Wet rot of flower) from Egusi melon plants in Nigeria.

The most frequently occurring field fungal pathogens associated with blight from this study (Fig. 1) were Choanephora cucurbitarum (29.8\%), followed by L. theobromae $(26.0 \%)$ and Curvularia lunata (9.3\%). Some of these recently identified Egusi melon pathogens $(C$. cucurbitarum, Colletotrichum spp., Fusarium spp. and $L$. theobromae) have been earlier reported in Egusi melon (Bankole and Joda, 2004; Kehinde, 2008; 2011; 2013); while other 
identified Egusi melon fungi not observed in this study might not be associated with blight disease.

The observed uneven occurrence and distribution of the Egusi melon associated pathogens in the study areas might be due to variation in environmental factors such as temperature, relative humidity, soil $\mathrm{pH}$, soil fertility and preferred Egusi melon cultivars. Such differences in disease distribution have been described by Baimey et al. (2009) as a natural occurrence, resulting from differences in the host plant, soil, climate, cropping patterns and cropping history. Though in the same agro-ecology, there are some variations in the climate, soil type, cropping system and cultivar preference among the five Southwestern States (Eludoyin et al., 2017).

These effects of variations in climate on host susceptibility and plant infection mechanisms have been reported by Hellin $e t$ al. (2014). The common practice of mixed cropping among the Egusi melon farmers in South-western Nigeria (Kehinde, 2011) could vary the establishment and distribution of blight disease, especially where Egusi melon is mixed with blight susceptible crops. In States like Ondo and Ekiti with preference to Bojuri cv. which is a broad-leaf, disease development will differ from that of Oyo State where Bara cv. is prevalent.

Pathogenicity test confirmed Colletotrichum gloeosporioides, Lasiodiplodia theobromae, (Syn. Botryodiplodia theobromae) and Colletotrichum truncatum as causal organisms of leaf blight on Egusi melon (Plate 1). This is contrary to Kehinde's (2013) report of Didymella bryoaniae as the causal pathogen of leaf blight and fruit rot of Egusi melon. We could not observe gummy stem blight symptoms or exudation of gummy material and water soaked leaf lesions of the Egusi melon plants from the study area, which are characteristic of diseases by Didymella bryoaniae in cucurbits (Sudisha et al., 2006; Keinath, 2011). The different observation might be attributed to varying environmental factors such as relative humidity, temperature, soil moisture and soil $\mathrm{pH}$, capable of affecting fungi pathogenicity (Topit and Sovali, 2010).

The three identified leaf blight causal pathogens have been reported to have caused various diseases in many crops (Nasimento et al., 2010; Suparman et al., 2018). Lasiodiplodia theobromae was reported to have a very wide host range, causing diseases such as blight, dieback, root rot and post-harvest rot in different plants in the tropical and subtropical regions (Urbez-Torres et al., 2008; Kumar and Singh, 2009). It was reported as one of the major field pathogens in South East Nigeria (Bankole, 1998) that caused leaf blight on orchid (Catasetum fimbriatum) in Brazil (Lopes et al., 2009) and root rot and leaf blight symptoms on rice in Nigeria (Claudius-Cole, 2018). It is also a tropical and subtropical cosmopolitan soil borne fungus (Burgess et al., 2006), with a wide host range which includes banana, mangoes, cocoa (Twumasi et al., 2014), cassava, yams (Ogundana, 1983) and coffee and coconut (Rosado et al. 2016).

Many species of Colletotrichum similarly cause blights of aerial plant parts and postharvest rots (Saxena et al., 2016). Though known mainly for causing anthracnose, many Colletotrichum species also incite other diseases such as dieback, leaf spot, flower rot, fruit rot, stem end rot and root rot (Bruce $e t$ al., 2013). Colletotrichum truncatum causes anthracnose/pod blight of soybean (Jagtap et al., 2014); while Leaf blight of musli (Chlorophytum borivilianum) is caused by $C$. capscici (Sattar et al., 2005) and C. dematium (Banginwar et al., 2012). Leaf blight of Azadirachta indica by $C$. dematium has also been reported (Bhanumathi and Rai, 2007).

Leaf blight of Egusi melon is capable of causing economic damage on the crop in Nigeria and can reduce the photosynthetic ability of melon plants, making the plants more vulnerable to the effects of other diseases. The weather conditions of the survey area are conducive for fungal disease development. For instance, $C$. gloeosporioides requires high 
humidity of $85-90 \%$ and optimal temperature of $20-28{ }^{\circ} \mathrm{C}$ for survival on cassava (Bruggen et al., 1990). Such rain distribution and temperature range, which are obtainable in the southwestern Nigeria, might have enhanced the blight development by the fungi.

\section{CONCLUSION}

This study confirms the incidence of leaf blight on three Egusi melon varieties in the Southwestern Nigeria, and provides updates on the distribution of the disease. Blight is prevalent on "Bara" Egusi melon cultivar which is mostly preferred in the surveyed area and its incidence is highest on farms in Ondo State, but the least in Osun State. Twelve fungi are associated with blight on the crop; while Colletotrichum truncatum, C. gloeosporioides and Lasiodiplodia theobromae are the causal organisms of leaf blight disease of Egusi melon.

\section{ACKNOWLEDGMENT}

We appreciate the management of the Nigeria Agricultural Quarantine Service (NAQS) Moor Plantation Ibadan, Nigeria, for extending diagnostics facilities for this study.

\section{REFERENCES}

Adewusi, H.G., Ladipo, D.O., Sarumi, M.B. and Vodouhe, R. 2000. Egusi production, utilization and diversity in Nigeria. In: Agronomy in Nigeria. Polygraphics venture Ltd, Ibadan. pp. 94-100.

Agba, O.A. 2004. Effect of nitrogen and phosphorus on the growth and yield of Egusi (Colocynthis citrillus L.) in cross River State. Journal of Agriculture, Forestry and the Social Science 2(2):1-7.

Agba, O.A., Adinya, I.B., Agbogbo, E.A, Oniah, M.A., Tiku, N., Abam, P. and Lifu, M. 2009. Rivers, South-South Nigeria. Continental Journal of Agronomy 3:13-18.
Ajuru, M.G. and Okoli, B.E. 2013. The morphological characterization of the melon species in the family cucurbitaceae Juss. and their utilization in Nigeria. International Journal of Modern Botany 3(2):15-19.

Baimey, H., Coyne, D., Dagbenonbakin, G. and James, B. 2009. Plant-parasitic nematodes associated with vegetable crops in Benin: Relationship with soil physicochemical properties. Nematologia mediterranea 37:227-236.

Banginwar, Y.S., Ingle, S.T. and Kshirsagar, Y.L. 2012. Effective management of Colletotrichum dematium causing leaf blight of safed musli. International. Journal of Chemical Sciences 10(2):967-971.

Bankole, S.A. 1998. Postharvest fungal deterioration of melon seeds and its control. $\mathrm{PhD}$ Thesis, Department of Crop Protection and Enviromental Biology, University of Ibadan, Nigeria. 219pp.

Bankole, S. A. and Joda, A.O. 2004. Effect of lemon grass (Cymbopogon citratus Stapf) powder and essential oil on mould deterioration and aflatoxin contamination of melon seeds (Colocynthus Citrullus L.) African journal of Biotechnology 3(1):5259.

Barnett, H.L. and Hunter, B.B. 2003. Illustrated Genera of Imperfect Fungi. American Phytopathological Society Press, St. Paul, Minnesota, USA. 218pp.

Bhanumathi, A. and Rai, R.V. 2007. Leaf blight of Azadirachta indica and its management. African Journal of Agricultural Research 2:538-543.

Bruce, C.D.F., Fatima, C.D. and Michereff, S.J. 2013. Biology of Colletotrichum spp. and epidemiology of the anthracnose in tropical fruit trees. Revista Caatinga 26:130-138.

Bruggen, P.V., Gregoire, D. and Marite, H. 1990. Temperature-induced alteration in the expression of susceptibility of cassava to Colletotrichum gloeosporioides f.sp manihotis. Journal of Phytopathology 130:46-58. 
Burgess T.I., Barber P.A., Mohali S., Pegg G., de Beer W. and Wingfield, M.J. 2006. Three new Lasiodiplodia spp. from the tropics, recognized based on DNA sequence comparisons and morphology. Mycologia 98:423-435.

Chiejina, N.V. 2006. Studies on seed-borne pathogens some Nigerian melons. AgroScience: Journal of Agricultural Food Environment and Extention 5.1:13-16.

Claudius-Cole A.O. 2018. Lasiodiplodia theobromae in the Root Rot Disease Complex of Rice. Journal of Rice Research 6(4): 1-5. doi:10.4172/2375-4338.1000197

Denton, L.A. and Adeniran, M.O. 1990. Geographical distribution and performance of the major seed types of Egusi melon (Citrullus lanatus Thunb. Mansf.) in Nigeria. Journal of Horticultural Science 1:11-13.

Denton, L. and Olufolaji, A. O. 2000. Nigeria's most important vegetable crops. In: Agronomy in Nigeria. Akoroda, M.O. (Ed.). University of Ibadan, Nigeria. pp. 85-93.

Ebele, M.I. 2011. Evaluation of aqueous plant extracts to control rot fungi in pawpaw. Journal of Applied Biosciences 37:2419 2424.

FAO. 2016. FAOSTAT. FAO Statistics Division. www.faostat.org. Retrieved June 10, 2017.

Fayemi, P.O. 1999. Local extraction of melon oil (Nigerian vegetable). Heinemann Educational Books PLC Ibadan, Nigeria. pp. 138-139.

Hellin, J., Bellon, M.R. and Hearne, S.J. 2014. Maize landraces and adaptation to climate change in Mexico. Journal of Crop Improvement 28(4):484-501, doi: 10.1080/154275 28.2014. 921800

Jackson, B.A., Ademade, C.A., Azogu, I.I. and Oni, K.C. 2013. Melon pod fermentation and its effects on physiochemical characteristics of melon seeds. Academic Journals 8(17):664-669.
Jagtap, D.P., Gavale, D.S. and Utpal, D. 2014. Control of Colletotrichum truncatum causing anthracnose /pod blight of soybean by aqueous leaf extracts and biocontrol agents. Legume Research 37(3):329 - 334 doi:10.5958/j.0976-0571.37.3.050

Kehinde, I.A. 2008. Identification and control of field and storage fungal pathogens of Egusi melon: Citrullus lanatus (Thumb) Mansf. in Southwestern Nigeria. PhD. Thesis. Department of Crop Protection and Environmental Biology, University of Ibadan, Nigeria. 211pp.

Kehinde, I.A. 2011. Response of melon cultivars to natural infection by diseases in Southwestern Nigeria. International Journal of Biology 3(4):47-55

Kehinde, I. A. 2013. Characteristic symptoms of melon diseases caused by fungi in Southwestern Nigeria. African Journal of Agricultural Research 8(46):5791-5801.

Keinath, A.P. 2011. From native plants in Central Europe to cultivated crops worldwide: The emergence of Didymella bryoniae as a cucurbit pathogen. Horticultural Science 46:532-535.

Klement, Z.A., Mavrids, K.R. and Vidaver, A. 1990. Methods in phytobacteriology. Klement, Z., Rudolph, K. and Sands, D.C. (Eds.). Akademia Kiado, Budapest 1(5):95-124.

Kumar, S. and Singh, L. 2009. Lasiodiplodia theobromae is a mycoparasite of a powdery mildew pathogen. Mycobiology 37(4):308309.

Lopes, U.P., Zambolim, L. and Pereira, O.L. 2009. First report of Lasiodiplodia theobromae causing leaf blight on the orchid Catasetum fimbriatum in Brazil. Australasian Plant Disease Notes 4:64-65.

Lowe, J. and Soladoye, M.O. 1990. Some changes and correction to names of Nigerian plants since publication of flora of West Tropical African and Nigeria Trees $2^{\text {nd }}$ ed. Nigerian Journal of Botany 3:124. 
Nasimento, R., Mizubuti, E.S.G., Camara, Statistical Analysis System (SAS). 2008. SAS M.P.S., Ferreira, M.F., Maymon, M., Freeman, S. and Michereff, S.J. 2010. First report of papaya fruit rot caused by Colletotrichum magna in Brazil. Plant Disease 94:1506.

Ogundana, S.K. 1983. Life cycle of Botryodiplodia theobromae, a soft rot pathogen of yam. Journal of Phytopathology 106:204-213.

Ogunremi, E.A. 1978. Effect of nitrogen on melon (Citrullus lanatus) at Ibadan, Nigeria. Experimental Agriculture 14:351365.

Oyolu, C. 1977. Quantitative and qualitative study of seed types in Egusi (Colocynthis citrullus). Tropical Science 24(2):93-98.

Philip, T. A. 1977. An Agricultural Notebook (With special reference to Nigeria). Longman Group Ltd. London, UK. 312pp.

Rosado, A.W.C., Machado A.R., Freire F. das C.O. and Pereira, O.L. 2016. Phylogeny, identification, and pathogenicity of Lasiodiplodia associated with postharvest stem-end rot of coconut in Brazil. Plant Disease 100:561-568.

Sattar, A., Alam, M, Abdul-Khaliq, Shukla, R. S. and Khanuja, S.P.S. 2005. First report of a leaf blight disease of Chlorophytum borivilianum caused by Colletotrichum capsici in northern India. New Disease Report 11:36.

Saxena, A., Raghuwanshi, R., Gupta V. K. and Singh, H.B. 2016. Chilli Anthracnose: The epidemiology and management. Frontiers in Microbiology 7:1527-1535. Doi: 10.3389/fmicb.201 6.01527.

Schippers, R.R. 2000. African indigenous vegetables. Cal an overview of the cultivated species. Natural Resources Institute/ACP-EU Technical Centre for Agricultural and Rural Cooperation, Chatham, UK. 214pp. user's guide version 9.2, SAS Institute Incorporated. Cary, North Carolina, USA. pp. 115-125.

Sudisha, J., Niranjana, S.R, Umesha, S., Prakash, H.S. and Shetty, H.S. 2006. Transmission of seed-borne infection of muskmelon by Didymella bryoniae and effect of seed treatments on disease incidence and fruit yield. Biological Control 37:196-205.Doi:10.1016/j.bio control.2005.11.018.

Suparman, Rahmiyah, M., Pujiastuti, Y., Gunawan, B. and Arsi. 2017. Cross inoculation of anthracnose pathogens infecting various tropical fruits. IOP Conference Series: Earth and Environmental Science. International Symposium on Food and Agro-biodiversity (ISFA), held in Semarang, Indobesia. 102:1-8. doi:10.1088/1755-1315/102/1/ 012080

Topit, I. and Sovali, P. 2010. The occurrence and severity of rust diseases of winter rye in Estonian climatic conditions. Agronomy Research 8(3):735-742.

Twumasi, P.A., Ohene-Mensa, G. and Moses, E. 2014. The rot fungus Botryodiplodia theobromae strains cross infect cocoa, mango, banana and yam with significant tissue damage and economic losses. African Journal of Agricultural Research 9:613-619.

Urbez-Torres, J.R., Leavitt, J.C., Guerrero, J.G. and Gubler, W.D. 2008. Identification and pathogenicity of Lasiodiplodia theobromae and Diplodia seriata, the causal agents of Canker. Disease of Grape vines in Mexico 92(4):519-529.

van der Vossen, H.A.M., Denton, O. A. and El Tahir, I.M. 2004. Citrullus lanatus In: Grubben, G.J.H. and Denton, O.A. (Eds.). Plant resources of Tropical Africa vegetables. Wageningen. The Netherlands. CTA; Leiden, The Netherlands: Buckhuys Publishers. pp. 185-191. 